\title{
WPS3615
}

\section{KEEPING ANIMAL SPIRITS ASLEEP: THE CASE OF CHILE}

\author{
Sebastián Sáez
}

sebastiansaez@tradenet.cl

World Bank Policy Research Working Paper 3615, May 2005

The Policy Research Working Paper Series disseminates the findings of work in progress to encourage the exchange of ideas about development issues. An objective of the series is to get the findings out quickly, even if the presentations are less than fully polished. The papers carry the names of the authors and should be cited accordingly. The findings, interpretations, and conclusions expressed in this paper are entirely those of the authors. They do not necessarily represent the view of the World Bank, its Executive Directors, or the countries they represent. Policy Research Working Papers are available online at http://econ.worldbank.org. 


\section{KEEPING ANIMAL SPIRITS ASLEEP: The Case of Chile by Sebastián Sáez}

\section{Summary}

Chilean legislation is quite conservative, especially compared with international practice. However, its application has not been free of criticism, and it proved necessary to seek mechanisms that combine limitations set forth in the GATT/WTO regulations and others self-imposed by Chilean law.

Legislation on anti-dumping measures was introduced in Chile in 1992. The Distortions Commission has recommended and the President has adopted such measures on just six occasions, of which two correspond to extensions of existing measures. Legislation on safeguard measures was introduced in 1999. In the 1999 - 2002 period, sevensafeguard measures were adopted. The traditional agricultural sector was the main user of the measures, and no measure was in place for more than 12 months.

The context in which the Commission was created in 1981 and the type of measures adopted by this entity support the idea that the objective of the Commission was to alleviate the political pressures generated by the difficult economic situation rather than to correct problems originated by the "price distortions of goods." In the second half of the 1980's, the Commission supported the liberalization process that started in 1985. Adopting safeguard legislation in 1999 helped to gain approval of further tariff reductions from 11\% to $6 \%$.

During the decade of the 1990's and until the present day, the philosophy of minimal use to further liberalization has been maintained. The legislation has undergone modifications to adjust the instruments used to support the economic opening and international commitments. 


\section{KEEPING ANIMAL SPIRITS ASLEEP: THE CASE OF CHILE}

Sebastián Sáez

The multilateral trading system has defined the instruments that can be adopted by the members of the World Trade Organization (WTO), under certain conditions, to correct trade distortions (subsidies and dumping practices), and to prevent the damage that a sudden increase of imports may cause. These instruments have been part of trade regimes since the end of the $19^{\text {th }}$ century and the beginning of the $20^{\text {th }}$ century.

The thesis presented in this chapter is that the political economy of contingent trade protection demands at least an institutional regime that will significantly reduce the possibility that these instruments be captured by private interests or the economic or political context of a country. At the same time, under certain conditions, experience indicates that these instruments can be a useful tool to support economic opening, as they offer society mechanisms that can temporarily alleviate and/or facilitate the adjustment that a sector may need in the transition to the new context of economic liberalization.

This paper examines the origin, evolution and operation of the adoption of safeguard measures and anti-dumping duties in Chile. The first section studies the evolution of legislation from 1981 to the present. The second section examines the measures adopted and the sectors which have benefited from them. The third section analyzes how the Distortions Commission works. Finally, the fourth section presents an assessment of the performance of the Chilean system,and examines proposals for improvement.

\footnotetext{
- The author would like to acknowledge J. Michael Finger and Julio J. Nogués for their invitation to participate in this project. The author would also like to acknowledge the comments of Diana Tussie and the participants of the seminar where a preliminary version of this paper was discussed. During the preparation of this paper, useful comments from several experts were received, in particular from Juan S. Araya, Alvaro Espinoza, and Ambassador Alejandro Jara, who intently and patiently read the paper and made suggestions that contributed to improve it. Evelyn Caserio collaborated in the research of basic and statistical background data. As is usual, all errors or omissions are the author's sole responsibility.
} 


\section{The Development of Chilean Legislation on Unfair Competition}

For a number of reasons, Chile's trade policy reform process differs from that of the rest of Latin America. In the first place, this process started at the end of 1973, earlier than in the rest of the region. This gives reforms a degree of maturity that contributes to the stability of trade policy and the continuous opening process that the economy has experienced in the context of democracy. Secondly, these reforms took place in the context of a military regime that did not need to seek support to enforce its policies. Neither did it give the public any explanation for the negative consequences that reforms had at the begining. Therefore, it was not necessary to create instruments that would temporarily alleviate their effects, or to establish mechanisms that would promote a gradual adjustment to the new conditions. In the third place, the Chilean trade reform is characterized by its wide scale and speed. In fact, as graph 1 shows, in June 1979 tariffs decreased from an average of over $90 \%$ to a uniform $10 \%$ level. Additionally, the currency exchange was fixed for nearly 3 years from June 1979 to mid 1982, a period during which economic policy adopted the monetary approach to the balance of payments. All this took place in a context where the set of trade policy instruments in force in September 1973 was disassembled at the same time as tariffs were reduced (quotas, prohibitions, advance deposits, among others). Besides, trade opening took place and was a key piece in the macro-economic stabilization process launched by authorities. Finally, it is important to take into account that Chile's trade reform process is part of a larger scale institutional transformation process, which coherently encompassed diverse aspects of Chilean society such as its political regime, the role of the state in the economy, the general economic framework, and social policies as they had developed throughout the $20^{\text {th }}$ century. 


\section{Graph 1: Tariffs and Real Exchange Rate, 1973-2003}

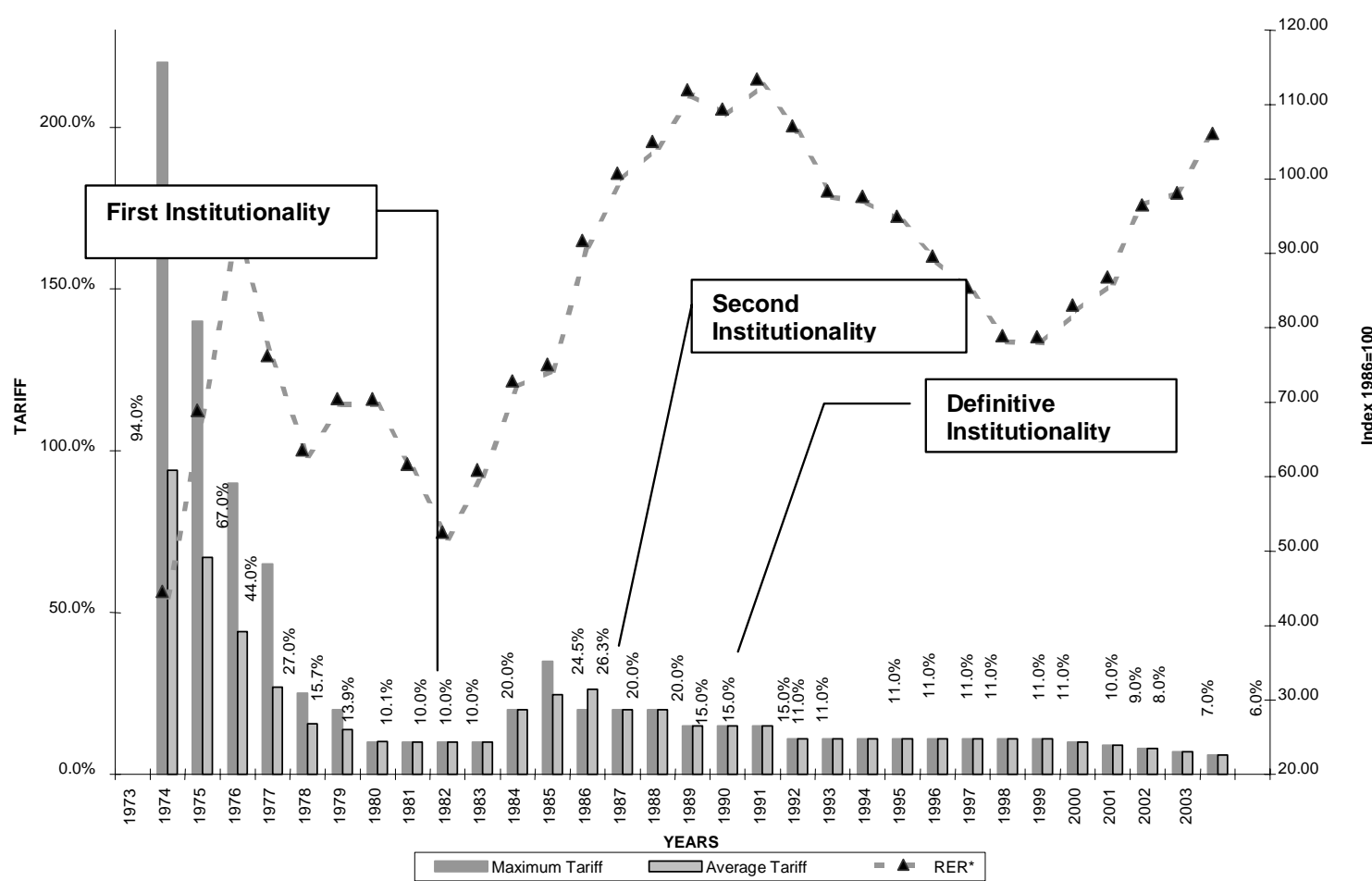

${ }^{\star}$ RER: real exchange rate

Sources: Tariffs: French-Davis (1980), Meller (1996) and the author's analysis. Real exchange rate provided by $\mathrm{R}$. French-Davis, following calculus methodologies described in French-Davis (2003).

Although in 1973 protection was initially very high, at the end of the unilateral liberalization process, when the tariff level reached $10 \%$, it could have been justified to introduce contingent protection instruments to support the adopted policy. Nevertheless, this only happened during the great economic crisis of 1982.

In the framework of the trade negotiations of the Tokyo Round, Chile signed the GATT Subsidy Code, because the existence of subsididized imports was considered to be the only situation that justified a temporary protection in favor of the domestic industry. Conversely, the economic rationale of safeguard measures was less sustainable. Besides, in their original form these measures contemplated compensations for the countries affected by them, which discouraged their application. Finally, it was considered that in an open economy, anti-dumping duties could lead to protectionist measures that would favor sectors that might feel affected by the opening and could have political influence to get protection. Besides, they did not have a solid economic basis. 
Table 1: The Development of Legislation, 1981-2000

\begin{tabular}{|c|c|c|c|c|}
\hline YEAR & GATT/WTO & LAW & $\begin{array}{c}\text { RESPONSIBLE } \\
\text { ENTITY }\end{array}$ & INSTRUMENTS \\
\hline 1981 & $\begin{array}{c}\text { Subsidies Code/Tokyo } \\
\text { Round/ GATT } 1947\end{array}$ & $\begin{array}{l}\text { Decree } \\
\text { NN}^{0} 742\end{array}$ & Central Bank & $\begin{array}{l}\text { Compensatory } \\
\text { adjustments (CA); } \\
\text { minimum customs values } \\
\text { (MCV); surcharges. }\end{array}$ \\
\hline 1986 & $\begin{array}{c}\text { Subsidies Code/Tokyo } \\
\text { Round/ GATT } 1947\end{array}$ & Law No18,525 & Central Bank & CA; MCV; surcharges \\
\hline 1989 & $\begin{array}{c}\text { Subsidies Code/Tokyo } \\
\text { Round/ GATT } 1947\end{array}$ & $\begin{array}{l}\text { Law } \mathrm{N}^{\circ} \\
18,840 \text { and } \\
\mathrm{N}^{0} 18,908\end{array}$ & $\begin{array}{l}\text { Distortions } \\
\text { Commission }\end{array}$ & CA; MCV; surcharges \\
\hline 1992 & $\begin{array}{c}\text { Subsidies Code/Tokyo } \\
\text { Round/ GATT } 1947\end{array}$ & $\begin{array}{l}\text { Law } \\
\text { № } 19,155\end{array}$ & $\begin{array}{l}\text { Distortions } \\
\text { Commission }\end{array}$ & $\begin{array}{l}\text { CA; MCV; surcharges; } \\
\text { anti-dumping duties. }\end{array}$ \\
\hline 1995 & WTO & $\begin{array}{l}\text { Law } \\
\text { No } 19,383\end{array}$ & $\begin{array}{l}\text { Distortions } \\
\text { Commission }\end{array}$ & $\begin{array}{l}\text { CA; MCV, surcharges; } \\
\text { anti-dumping duties }\end{array}$ \\
\hline 1999 & WTO & $\begin{array}{c}\text { Law } \\
\text { № } 19,612\end{array}$ & $\begin{array}{l}\text { Distortions } \\
\text { Commission }\end{array}$ & $\begin{array}{l}\text { Safeguards; anti-dumping } \\
\text { duties; CA }\end{array}$ \\
\hline
\end{tabular}

Source: Diario Oficial, several issues.

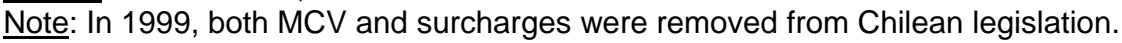

In October 1981, the Subsidies Commission was created and installed in Chile's Central Bank $(\mathrm{BCCH})$. Its role was related to initiating, conducting and concluding investigations on subsidized imports, and to submit its conclusions to the Ministry of Finance, which could use them to adopt compensatory adjustments in the form of "tariff surcharges" which consisted in an increase in the tariff up to the maximum level of $35 \%$ consolidated by Chile in the Tokyo Round. Likewise, the Commission was entitled to recommend the adoption of minimum customs values (MCV).

In an attempt to increase its representativeness, at the end of 1985 the composition of the Subsidies Commission was modified to include members from the Ministries of Economy and Foreign Affairs, the National Customs Service and the anti-trust authority (Fiscal Nacional Económico, FNE). The Commission continued to be chaired by the BCCH (see Table 1).

In 1986, Law $\mathrm{N}^{\circ} 18,525$ was passed. It created the "National Commission for Investigations on Imports Price Distortions" ${ }^{1}$, known as the National Commission for Price

\footnotetext{
${ }^{1}$ Before Law 18,525, article 186 of Law 16,464 delegated the faculty to suspend, reduce or raise customs duties to the President of Chile. As from the entry in effect of the Constitution of 1980
} 
Distortions (CNDP, or the Commission). It coexisted with the Subsidies Commission, which was based in the $\mathrm{BCCH}$ and as said, investigated applications against subsidies. Instead, the new Commission had a wider scope of action as it focused on "price distortions". Finally, with the promulgation of Law 18,840 in 1989, the constitutional organic law of the $\mathrm{BCCH}$ which established the substantive provisions over this institution and implemented the autonomy set forth in the Constitution of 1980 , and Law $N^{\circ} 18,908$ of January 1990, both commissions were merged. An important change introduced was the faculty to initiate an investigation without having received a written application by or on behalf of a domestic industry.

The National Commission was thus constituted in the general terms as it operates at present, by two representatives from the $\mathrm{BCCH}$, one representative from the Minister of Finance, one representative from the Minister of Economy, one representative from the Ministry of Foreign Affairs, the Director of the National Customs Service and the and the Head of FNE, who chairs $i^{2}$. In 1995, by means of a Law, a representative from the Ministry of Agriculture also joined the Commission. The Technical Secretariat of the Commission, which is in charge of conducting investigations on price distortions, is based in the $\mathrm{BCCH}$.

At the beginning of the 1990's, authorities foresaw that in the context of the Uruguay Round and the possibility of subscribing the Customs Valuation Code or a successive agreement, MCV could not continue to be applied to correct "price distortions". Besides, in a context in which continuous trade opening was foreseen - through unilateral liberalization or trade agreements- this instrument and the tariff surcharges would disappear as contingent protection.

Therefore, Law $N^{\circ} 19,155$ of August 13th 1992 entitled the Commission to recommend authorities to adopt anti-dumping duties and discontinue practices with less adequate instruments such as surcharges and MCV. This modification was opposed by orthodox economists, who, from a theoretical standpoint, correctly argued that in an open economy such as Chile's it would be impossible for a company to practice dumping since it would not be able to permanently hold a leading market position and would experience mid-term losses if it kept this strategy. On the other hand, there were sectors that

establishing the legal reserve principle, the duty (both the rate and the substantial elements that determine it) should be established by law, and this action cannot be delegated to the administrative authority.

${ }^{2}$ FNE is in charge of investigating actions against market competition, and of submitting its findings to the relevant authorities. 
considered that it was very difficult to continue with the liberalization process if properly regulated escape clauses subject to disciplines to control the application of this type of measure were not contemplated.

Finally, Law N 19,612, which was approved in May 31 1999, gave the President of Chile the possibility to adopt safeguard measures in compliance with article XIX of GATT and the corresponding WTO Agreement based on a report from the Distortions Commission. The legislation incorporated the form of adopting safeguard measures in compliance with the provisions of some bilateral agreements signed by Chile. At the same time, the possibility of adopting surcharges in the terms contemplated by the original law and MCV was eliminated.

\section{The Application of Measures through Time}

As Graph 2 indicates, the first version of the Commission was very active. According to the data available for the period between October 1981 and December 1985, 155 applications were submitted to the Commission, an investigation was conducted for 90 cases (58\%), and definitive measures were adopted for 47 cases investigated - 52\% or $30 \%$ of the applications originally made (see Graph 1 and Finger,1987).

Of the measures adopted, $76 \%$ were tariff surcharges and $22 \%$ were MCV. Concerning the sectors protected, the textile sector was predominant with $37 \%$ of the measures (all of them surcharges), followed by electrical products (8\%), and metal mechanics $(7 \%)$, see Table $2^{3}$.

In the 1981-1990 period, the difficulties generated by the requirements of the GATT Code - especially the requirement of the existence of a subsidy - and the fear of retaliation from the trade partners affected by Chile's measures, explain why the instrument that was most frequently used by authorities was tariff surcharges ${ }^{4}$. The adoption of this instrument arose from the sovereign decision to modify tariffs up to a

3 These numbers refer to the $1981-1987$ period. See Banco Central de Chile (2003) and www.cndp.cl.

${ }^{4}$ In fact, in some cases there were Latin American countries that expressed their intention to adopt disguised restrictions if Chile adopted countervailing duties against their exports, as they considered that such a measure would lead developed countries to react against them. 
consolidated maximum of $35 \%$ without infringing GATT obligations ${ }^{5}$, although an investigation proving injury or threat thereof was necessary in order to adopt measures. The same requirement applied to the adoption of MCVs.

\section{Graph 2: Applications Submitted and Investigations Initiated, 1981-2002}

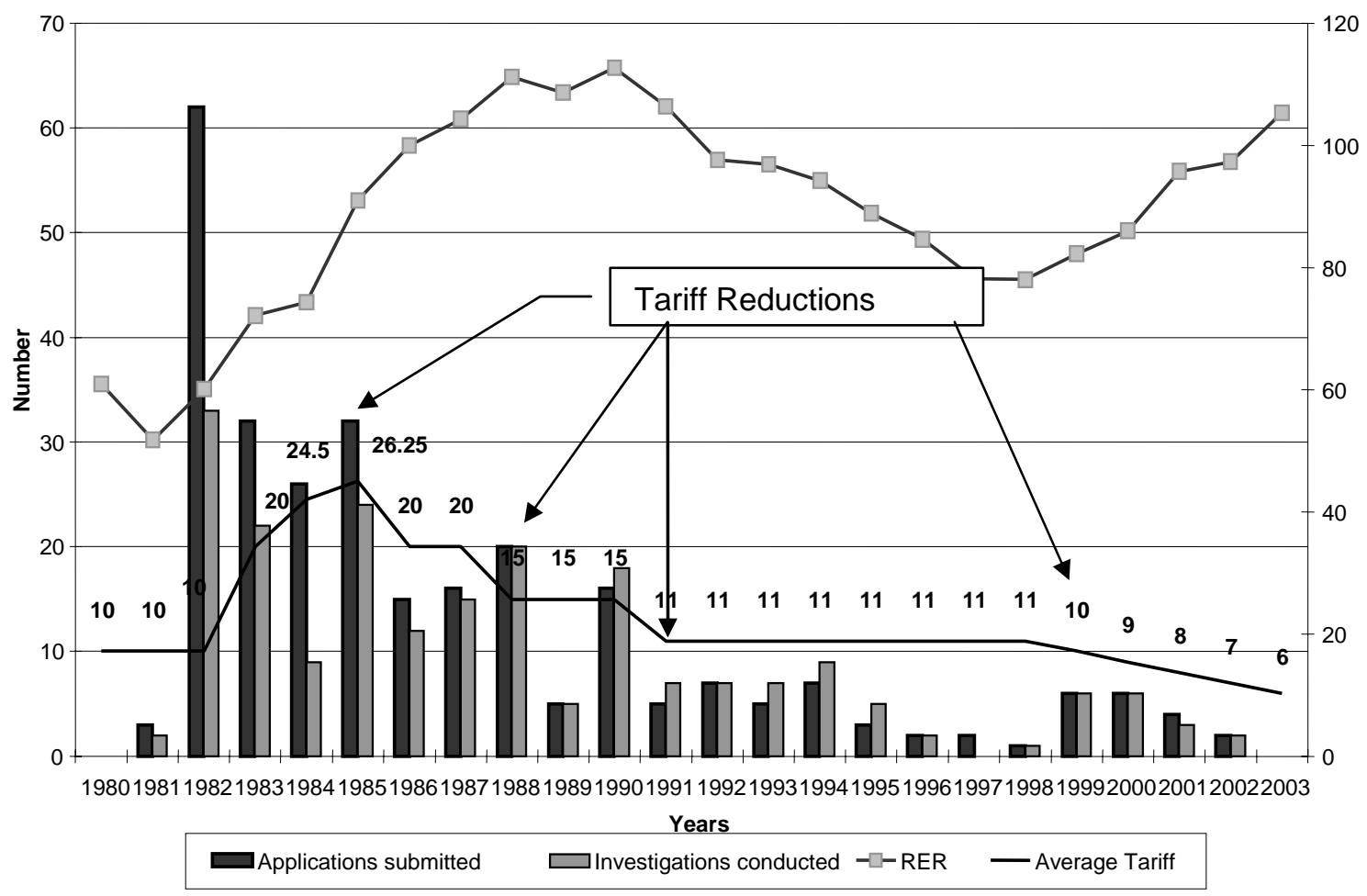

Source: Central Bank of Chile and www.cndp.cl , and Graph 1.

From the point of view of resource allocation, these measures -surcharges and MCV- were inefficient, as they affected imports independently of their origin or whether their prices were distorted or not. Consequently, it was presumed that there was a "distortion" in international markets in general and companies were forced to choose more expensive suppliers. Besides, when these measures were applied to intermediate goods, the effective protection of the final good was affected. However, apart from the domestic

\footnotetext{
${ }^{5}$ In the relevant section, Article 10 pointed out that " 3 per cent, 5 per cent, 8 per cent, 10 per cent, 12 per cent, 15 per cent, 18 per cent and 20 per cent surcharges should be established ad valorem"....
} 
context, it is important to take into account the international context, which explains the type of measures adopted by authorities. In fact, Latin America was facing a serious economic crisis and many countries, especially those with the largest relative size, maintained subsidies that made it difficult to target the measures on certain origins as they created incentives to deviate imports from those countries that were not affected by the protective measures. This reduced the effectiveness of the measures adopted.

In the 1986 - 1992 period, tariff surcharges were applied in $41 \%$ of the investigations that concluded with recommendations, MCV in 53\% and countervailing duties in just 6\% (www.cndp.cl). Except for one case, it is worth noting, however, that countervailing duties were often applied only between 1990 and 1992. The use of MCV was aimed to "punish" imports whose prices were more "distorted." Thus, the goal was to soften the impact of protection, as it was applied independently of origin and it affected mainly those imports whose prices were more "distorted", or in other words, lower. During this period, a sensitive reduction of the number of applications submitted to the Commission is observed, although the number of applications and investigations increased as tariffs were lowered (1985 and 1988). This shows that these measures served as a temporary deviation from the liberalization policy. Or rather they supported the opening, as they gave an option to the sectors that were more sensitive or reluctant to this policy. With the return of democracy in 1990, there was an important increase in the number of applications, probably with the expectation that in the new political context authorities would be more inclined to grant protection. When this failed to happen, applications and investigations decreased again in 1991 and 1992 (see Graph 2).

Concerning the sectors that resorted to these instruments, the predominant ones continued to be textiles with $55 \%$ of the measures adopted, dairy products (10\%), metals and metal mechanics (10\%), and electrical products (7\%) (see Table 2).

In the period from 1993, when this type of measure is introduced, to 1997, only 6 anti-dumping duties were adopted but more recently between 1998 and 2003, no new measures have been implemented. Between 1993 and 1998 tariff surcharges were not adopted. There were only four MCV in 1993 and 1994, and only one countervailing duty. Between 1999 and 2003 there were seven safeguard measures adopted. Since 2002 only one application has been submitted for safeguards against fructose imports and there have not been new investigations. Summing up, during the 1990's and in recent years, the Commission faced relatively lower levels of activity. 
It is useful to try to understand which variables explain the evolution of the investigations performed by the Commission. For that purpose, we have undertaken a simple econometric regression where the dependent variable is a logarithm of the applications submitted and the independent variables are a constant, the logarithm of the gross domestic product (GDP) and the real exchange rate (RER) of the previous period. A dummy variable was included from 1999 to 2002, when the safeguard legislation was introduced, to capture any possible change in policy from the moment the legislation was modified.

(1) LAPPLICATIONS= 57,70391 -1,147683 LRER (-1) -3,007096 LGDP (1) + 1.069985 DU 99 $(10,03122) \quad(-2,213121)$ $(-8,459161)$ $(3,199322)$

DW: 2,485215

$R^{2}: 0,859129$ $R^{2}$ adjusted: 0,834270

As it is reflected by the results of the regression, the applications submitted are a function of GDP and the RER lagged one year. The elasticity of the previous year's GDP is 3 and of the real exchange rate, 1.14 are statistically significant. The positive sign of the dummy variable, indicates that the introduction of safeguards had created expectations of a change of regime. This is reflected in the number of applications submitted after the legislation was approved (12 applications in 1999). However, this is not validated by the behavior of the Commission, which adopts 5 safeguard measures between 1999 and 2000.

(2) LINITIATED $=48,45148 \quad-2,711487$ LGDP

$(6,152791)(-5,562588)$

(1) $-0,211594$ LRER $(-0,299738)$

(1) $+0,724832$ DU 99 $(1,654273)$

DW: 1,680560

$R^{2}: 0,713528$

$\mathrm{R}^{2}$ adjusted: 0,665783

This exercise was also performed using initiations as the dependent variable. In this case, the RER is not a relevant variable as the measures adopted are better explained by the GDP behavior of the previous year. In relation to the behavior of the Commission , this can indicate that the expectations of those who seek protection due to the appreciation of the RER are not validated. The dummy variable continues to be significant, which again 
indicates an expectation that the Commission would change its policy. Specifically, once the legislation was approved, the Commission tended to initiate an important fraction of the applications, and on three occasions the Comission self-initiated investigations (of a total of 15 from 1990 to 2002), thus validating a possible change of policy. Nevertheless, later this expecation was frustrated by the low number of measures adopted. 


\section{Table 2: Definitive Measures of the National Commission for Price Distortions and Sectors Affected}

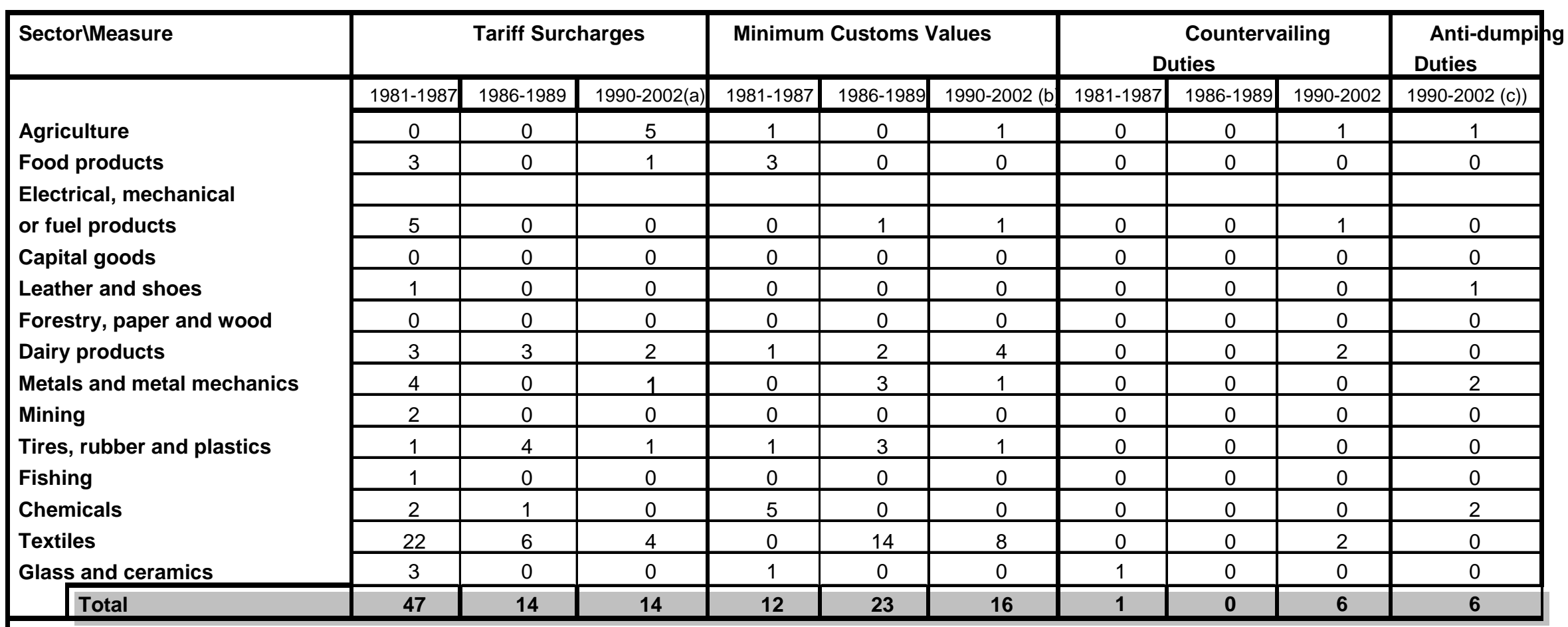

Source: Central Bank of Chile (2003), www.cndp.cl

Note:

In 2003, there were no investigations and no measures of any kind were adopted

a) As from 1999, surcharges correspond to safeguard measures. The former system of surcharges up to a $35 \%$ level was eliminated;

b) As from 1999, MCV were removed from Chilean legislation;

c) Before 1992, anti-dumping duties were not

applied. 


\section{The Operation of the National Commission for Price Distortions (CNDP)}

The role of the CNDP is to "acknowledge" applications against price distortions on imported merchandise. To proceed with the application, an investigation must be undertaken. The Commission is to publish the initiation date of the investigation and its subject matter in the Official Bulletin (Diario Oficial) within five working days after the application is submitted. The Commission has to receive the background data that the interested parties want to submit, and request the necessary reports within 30 days after the application is published. Upon request from the interested parties and before presenting its conclusions, the Commission is to hold a public hearing.

The Commission is entitled to carry out ex-oficio investigations when the data available justifies it. In these cases the procedure followed is the same as for cases initiated through an application. The stages in the investigations and their development are in accordance with the general guidelines of WTO agreements (see Table 3).

It is the President of the country, through the Minister of Finance, who finally determines which products will be subject to measures, their amount and duration, in accordance with the matter investigated and the report of the Commission ${ }^{6}$. This provision would imply that the President can follow the recommendations on the measures presented by the Commission or not. However, if the President adopts a measure, it cannot be more restrictive than the one recommended by the Commission. For example, if the Commission recommends that a $10 \%$ anti-dumping duty should be adopted, the President is entitled to apply a lower duty or one equal to $10 \%$. Likewise, a measure can be extended for an additional year, without a limit of years, provided a previous de novo investigation is conducted by the Distortions Commission to recommend maintaining the measure or modifying it. The request for renewal must be made by one of the interested parties in the case of safeguards, or it can be a decision of the Commission in the case of dumping and subsidies. In the latter case, the request for renewal triggers a ex-oficio investigation.

\footnotetext{
${ }^{6}$ According to the Chilean Constitution, duties can be established or modified only by means of a law proposed by the Executive Power and approved by the Parliament. In this case, articles 9 and 11 of Law 18,525 establish the duties and requirements that they must fulfill for their application. The responsibility of the President is only to confirm compliance with these requirements through a supreme decree after having received a favorable report from the Commission.
} 
Table 3: Investigation Procedure and Stages

\begin{tabular}{|c|c|c|}
\hline \multirow{2}{*}{ Investigation Stages } & \multicolumn{2}{|r|}{ Timeframes } \\
\hline & Antidumping & Safeguards \\
\hline \multicolumn{3}{|l|}{ Submission of Application or Request } \\
\hline Dumping/Subsidy Application Form & - & - \\
\hline Safeguard Request Form & - & - \\
\hline \multicolumn{3}{|l|}{ Acceptance of Applications } \\
\hline \multicolumn{3}{|l|}{ Investigation Process } \\
\hline Initiation of investigation and timeframes & 1 year - Maximum 18 months in exceptional cases. * & 90 days * \\
\hline Notification to parties & 15 days to make comments or observations. & Immediately after taking a measure \\
\hline Receipt of evidence & 30 days & 30 days \\
\hline Access to information related to the investigation & \multicolumn{2}{|c|}{$\begin{array}{l}\text { Once the initiation of an investigation is notified, the Distortions Commission makes the complete text of the public version } \\
\text { of the application available to all interested parties involved. }\end{array}$} \\
\hline Hearings & $\begin{array}{l}\text { The Distortions Commission fixes the date, time and venue } \\
\text { of the hearing and notifies interested parties in writing. } \\
\text { The latter must communicate their intention to attend in writing } \\
\text { up to within the third working day before the hearing }\end{array}$ & $\begin{array}{l}\text { The date, time and venue of the hearing must be included in the notice } \\
\text { of initiation of investigations that is published in } \mathrm{D} \text {. O. } \\
\text { The parties who wish to attend must communicate their intention in writing } \\
\text { Up to within the third working day before to the hearing }\end{array}$ \\
\hline In situ visits & $\begin{array}{l}\text { When an investigation is initiated, the authorities of the exporting Member } \\
\text { and all companies known to be interested in carrying out in situ } \\
\text { investigations should be informed. }\end{array}$ & - \\
\hline Technical report & - & - \\
\hline Public notice of determinations & \multicolumn{2}{|c|}{$\begin{array}{l}\text { The Distortions Commission gives public notice of all preliminary or definitive determinations, positive or negative } \\
\text { and of the termination of an investigation. }\end{array}$} \\
\hline \multicolumn{3}{|l|}{ Recommendation of Measures } \\
\hline Recommendation of provisional measures & 60 days * & 30 days * \\
\hline Recommendation of definitive measures & \multicolumn{2}{|c|}{ Once an investigation is finished. They become effective as from the moment they are published in the Official Bulleting of the corresponding decree. } \\
\hline \multicolumn{3}{|l|}{ Termination of measures } \\
\hline Provisional measures & 4 months and 6 months in exceptional cases & 200 days at the most. \\
\hline Definitive measures & $\begin{array}{l}1 \text { year as from publication in the Official Bulletin. According to current } \\
\text { norms, the recommended measure cannot be higher than } \\
\text { the distortion margin. }\end{array}$ & $\begin{array}{l}1 \text { year as from publication in the Official Bulletin if there have not been provisional } \\
\text { measures. If provisional measures have been applied, the one year period is counted } \\
\text { As from the date of publication of the decree that instructs the application } \\
\text { of these measures. }\end{array}$ \\
\hline Extension of definitive measures & $\begin{array}{l}\text { Measures can be extended after a request is made and a new investigation } \\
\text { Is conducted. }\end{array}$ & $\begin{array}{l}\text { Safeguard measures can be extended only once for a period that cannot exceed one } \\
\text { year. } \\
\text { This request has to be made at least } 30 \text { days before the expiration of the original term. }\end{array}$ \\
\hline
\end{tabular}

* Timeframe as from the publication of the initiation of an investigation in the Official Bulletin (D.O). 
The law that created the Distortions Commission has been modified to incorporate the WTO agreements: new measures were added (safeguards) and others were eliminated (surcharges and MCV). However, the concept that the Commission is in charge of investigating "price distortions on imports" and that it is also responsible for safeguards, subsidies and dumping investigations has been kept. The question arises if there are "other distortions" on the prices of merchandise sold on international markets besides those mentioned here that should also be investigated by this Commission. Likewise, the coexistence of the terminology of the original law, including its timeframes, and of decrees that regulate the operation of the Commission and have not been updated with the provisions of WTO agreements - the ones that should prevail when investigations are conducted - could bring about some ambiguity and confusion.

A point that draws attention when studying the Chilean legislation is the double role that the $\mathrm{BCCH}$ plays . In fact, the $\mathrm{BCCH}$ acts as a member of the Commission with 2 representatives (25\% of the members) and at the same time, is responsible for its Technical Secretariat. In the latter capacity, the $\mathrm{BCCH}$ is in charge of conducting investigations and submitting to the Commission a report in which all the evidence gathered is analyzed. This double role has been maintained since the Chilean system was created. In 1989, when the Organic Constitutional Law of the $\mathrm{BCCH}$, which gave legal expression to the constitutional norm that established its autonomy was passed, the role of the $\mathrm{BCCH}$ as the Technical Secretariat of the Distortions Commission was maintained even though this entity was giving up almost all its functions in trade policy.

There are two reasons that can explain this decision. In the first place, there was a concern that the new democratic regime would be very sensitive to pressures from sectors that would demand trade protection ${ }^{7}$. Conversely, the $\mathrm{BCCH}$ would be less permeable to them by keeping a technical approach to investigations. Its weight in the Commission provided a balance that supported an "exclusively technical" approach.

In the second place, there is a budgetary issue, as transferring the functions of the Technical Secretariat to another public entity implied the need to provide it with the means and the technical training to perform this function. At present, the Technical Secretariat has sufficient budget to conduct investigations initiated by the Commission through applications or ex-oficio, as it is part of the functional structure of the $\mathrm{BCCH}$. This budget

\footnotetext{
${ }^{7}$ In fact, the number of applications submitted in 1990 proves that there was an expectation in this sense.
} 
allows the Technical Secretariat to pay higher market remunerations than the public sector, to hire additional full time or part time professionals when needed, to commission external studies - what has not been necessary so far - to carry out in situ visits, and in general, to access all the local and international statistical information that is necessary to conduct an investigation.

The Technical Secretariat is formed by a small group of professionals who are in charge of conducting investigations. These professionals also have other roles inside the Department of Trade Policy of the $\mathrm{BCCH}$, which reports to the Department of International Exchanges and Trade Policy. The work of the Secretariat is defined as exclusively technical, of low profile and protected by the global institutionality of the $\mathrm{BCCH}$. Thus, the political and public pressures that in many cases is excercisedduring investigations falls mainly on the members of the Commission, particularly on the representatives of Ministries, who adopt recommendations on the basis of the investigations performed by the Technical Secretariat. However, the law does not prevent Commission members from contributing additional evidence in the course of the investigation or during deliberations.

One of the functions of the Technical Secretariat is to explain to the interested parties the legal requirements of the WTO and of local laws that must be fulfilled to initiate and conduct an investigation. Another one is to analyze the evidence provided by the parties and to gather all the necessary information to prepare the technical report that is submitted to the Commission. The Technical Secretariat is also responsible for compliance with all the legal requirements of the WTO and Chilean legislation. The Technical Secretariat does not perform dissemination activities of its work, although it participates in seminars and other activities to which its members are invited to discuss aspects of Chilean law and of international legislations of general interest.

Throughout the years, the autonomy of the $\mathrm{BCCH}$ has been consolidated and its credibility in conducting monetary and exchange rate policies has been strengthened. Consequently, there have not been serious proposals to move the Secretariat out of this institution. 


\section{a. The Application of Anti-dumping Duties}

Since the legislation on anti-dumping measures was introduced, the Distortions Commission has recommended and the President has adopted this type of measure on just six occasions, out of which two correspond to extensions of existing measures (see Table 4). Chilean legislation takes the provisions of the WTO Agreement, which are "fully incorporated in (our) national legislation, and are therefore Chilean law in each and every part."8

Both Chilean legislation and the practice followed in investigations so far have maintained stricter and more restrictive criteria than those contemplated in the corresponding WTO agreements and in most member country legislations. In fact, measures have a duration of one year, and can only be extended through a previous de novo investigation. Furthermore, in the investigations that have been conducted so far, the following parameters have been applied ${ }^{9}$ :

i. The measure recommended to correct dumping takes into consideration the injury margin instead of the dumping margin;

ii. The injury margin is calculated, in general, on the basis of the prices of other competitors and not on the basis of domestic prices ${ }^{10}$;

iii. When calculating dumping margins on the basis of the domestic price of imports in the country of origin, sales below cost price are not excluded which reduces the dumping margin;

iv. The investigation is not always carried out against all imports from the origin reported in the application, but only against imports from the companies reported, although there are only some examples of this criterion;

v. The approach applied favors the determination of the causal relationship between the existence of dumping and the damage instead of analyzing simple correlations (one-track versus two-track approach); and

vi. Neither anti-elusion nor retroactive measures are applied.

\footnotetext{
${ }^{8}$ Responses given by the Government of Chile before the WTO. See G/ADP/W/156, G/SCM/W/163, November 28, 1995.

${ }^{9}$ See Peña (2001) for an analysis of the practical application of the provisions of the Antidumping Agreement in Chilean legislation.

${ }^{10}$ The technical criterion applied is the "non-dumped import price method". The "best information available" has not been frequently used and so far, the possibility of negotiating price agreements has not been applied either.
} 
Table 4: Anti-dumping Duties, 1992-2002.

\begin{tabular}{|c|c|c|c|c|c|c|c|c|}
\hline $\begin{array}{c}\text { D.O. } \\
\text { Initiatio } \\
\text { n Date }\end{array}$ & $\begin{array}{l}\text { Name of } \\
\text { Product }\end{array}$ & $\begin{array}{c}\text { Measure } \\
\text { Level }\end{array}$ & $\begin{array}{l}\text { Country } \\
\text { of Origin }\end{array}$ & $\begin{array}{l}\text { INCIDENCE } \\
\text { Countryl } \\
\text { Total (a) }\end{array}$ & \begin{tabular}{|c|} 
D.O. \\
Definitive \\
Measure - \\
Date \\
\end{tabular} & $\begin{array}{c}\text { Measure } \\
\text { Effective } \\
\text { Date }\end{array}$ & $\begin{array}{c}\text { Measure } \\
\text { Termination } \\
\text { Date }\end{array}$ & $\begin{array}{l}\text { Measure } \\
\text { Duration }\end{array}$ \\
\hline 18-11-93 & \begin{tabular}{|l|} 
Phtalic \\
Anhydride \\
\end{tabular} & $7,0 \%$ & Venezuela & $86 \%$ & 11-05-94 & |11-05-94 & |11-05-95 & 12 months \\
\hline $12-03-94$ & $\begin{array}{l}\text { Phtalic } \\
\text { Anhydride }\end{array}$ & $7,0 \%$ & Venezuela & $47 \%$ & 06-09-94 & 06-09-94 & 11-05-95 & 9 months \\
\hline $19-12-94$ & Wheat flour & $7,0 \%$ & Argentina & $95 \%$ & 05-05-95 & 05-05-95 & 05-05-96 & 12 months \\
\hline |09-02-95 & Shoes & $10,0 \%$ & China & $\begin{array}{l}\text { 64021900: } 30 \% \\
\text { 64029900: } 49 \% \\
\text { 64039900: } 23 \% \\
\text { 64039190: } 47 \% \\
\end{array}$ & 21-06-95 & 21-06-95 & 21-06-96 & 12 months \\
\hline $16-10-96$ & $\begin{array}{l}\text { Hot-rolled } \\
\text { steel rolls, } \\
\text { but for } \\
\text { thickness } \\
\text { smaller } \\
\text { than } 1.8 \\
\mathrm{~mm}\end{array}$ & $9,0 \%$ & $\begin{array}{l}\text { Russian } \\
\text { Federation } \\
\text { Ukraine }\end{array}$ & $\begin{array}{|lr|}72082500: & 100 \% \\
72082600: & 94 \% \\
72082700: & 15 \% \\
72083700: & 50 \% \\
72083800: & 64 \% \\
72083900: & 36 \% \\
72083700: & 6 \% \\
72083800: & 4 \% \\
72083900: & 0,2 \% \\
\end{array}$ & 24-04-97 & 24-04-97 & 24-04-98 & 12 months \\
\hline |05-05-98 & $\begin{array}{l}\text { Hot-rolled } \\
\text { steel rolls, } \\
\text { but for } \\
\text { thickness } \\
\text { smaller } \\
\text { than1,8 } \\
\mathrm{mm}\end{array}$ & $9,0 \%$ & $\begin{array}{l}\text { Russian } \\
\text { Federation } \\
\text { Ukraine }\end{array}$ & $\begin{array}{|lr|}72082500: & 0 \% \\
72082600: & 0 \% \\
72082700: & 0 \% \\
72083700: & 18 \% \\
72083800: & 7 \% \\
72083900: & 8 \% \\
72082600: & 14 \% \\
72082700: & 15 \% \\
72083700: & 1,1 \% \\
72083800: & 17 \% \\
72083900: & 1,7 \% \\
\end{array}$ & 24-10-98 & 24-10-98 & 24-10-99 & 12 months \\
\hline
\end{tabular}

Source: Technical Secretariat of the National Distortions Commission, Central Bank of Chile.

Note: imports from origin over total for the investigation year.

Nevertheless, the current practice used to assess the dumping cases could be modified by the Commission itself and consequently in a favorable atmosphere, this instrument could become a tool with a protectionist orientation. Therefore, it is necessary to seek mechanisms to ensure that the actual practice is consolidated. Even though it is not possible to establish full guarantees that a restrictive approach will be maintained, the role played by the leadership of the economic authorities responsible for conducting trade policy is important to maintain the actual orientation of this instrument.

In the context of its bilateral trade negotiations, Chile has sought to eliminate the application of anti-dumping measures, as the government has considered that their use is a protection mechanism rather than an instrument that will correct dumping practices (see Peña 2001, and Finger 1993). In the framework of the existing free trade agreement with Canada, both countries have agreed to eliminate anti-dumping measures in reciprocal 
trade. Likewise, the free trade agreement signed with the European Free Trade Area (EFTA), which is actually in the approval process in the respective Parliaments, eliminated the application of anti-dumping duties. However, these measures have not been replaced by the application of legislation on competition as is proposed by some authors. On the other hand, concerning the application of anti-dumping measures to third countries, both parties have the possibility to follow the procedures established by their legislation. In other words, criteria on the application of legislation were not harmonized. This is an advantage as it allows the continuation of a more restricted approach for the application of measures, instead of introducing complex and difficult procedures which are not related to the economic rationale of the instrument (see Peña, 2001).

\section{b. The Application of Safeguard Measures}

After the Economic Complementation Agreement with MERCOSUR and the Free Trade Agreement between Chile and Canada were signed, there was a debate on the trade diversion effects that these two agreements given the country's "relatively" high most-favored-nation rates. The Executive proposed to reduce the uniform applied rate from $11 \%$ to $6 \%$ in a period of 5 years. As part of the negotiation with the Congress, it was agreed that the legislation to adopt safeguard measures in compliance with Article XIX of GATT 1994 and the WTO Safeguards Agreement would be submitted.

This situation tends to favor the hypothesis that in the case of Chile, safeguard measures, as well as the use of measures in the decade of the 1980's, have complemented and supported the tariff reduction that took place in the second half of the 1990's. In other words, unilateral tariff reductions are accepted as long as there are protections for contingencies. The same happens in the trade negotiation processes in which temporary alleviation mechanisms are introduced.

Together with the adoption of safeguard legislation, the possibility to apply surcharges below the WTO bound tariff level, which are subject to less strict disciplines, and to apply MCV was eliminated. Finally, in agreement with the provisions of the treaties negotiated by Chile, the application of safeguards (bilateral or multilateral) was regulated.

The approved legislation is restrictively applied with respect to the provisions of Article XIX and the WTO Safeguards Agreement: when the recommended safeguard measure surpasses the WTO 25\% bound tariff, approval by the Distortions Commissions requires a special quorum equivalent to three-quarters of the members of the Commission. 
Additionally, safeguard meausres can only be ad-valorem tariffs and the legislation does not contemplate the application of quotas or specific duties. Likewise, safeguard measures can only be in force for a maximum period of one year, including the effective period of provisional measures. Safeguard measures can be extended for an additional one-year period provided a previous de novo investigation requested by the interested party accredits that the requirements of the Safeguards Agreement are fulfilled. In the case of an extension, a gradual dismantling schedule is established unless there are exceptional circumstances properly qualified by the Commission. To request the renewal of safeguards of a given product, no measures should have been applied for a period of two years ${ }^{11}$. However, this limitation is not explicitly established in the law that authorized the application of safeguards but it is derived from the provisions of the WTO Safeguards Agreement. In our view, these situations not explicitly contemplated in the law are a source of confusion when evaluating the framework of application of measures in Chile.

Furthermore, the bilateral agreements have established other limitations to the application of these measures, which add exceptions to them. Thus, safeguards have become more complex in terms of their application, administration and surveillance, and they are less effective.

Table 5 shows some of the rules on measures ${ }^{12}$. The first rule refers to temporary bilateral safeguards that exclusively affect trade between the parties and are normally applied during the liberalization period: once the tariff elimination program concludes, they cannot be applied except with the authorization of the affected party. A second category of safeguards introduced in treaties is aimed to address the situation of more politically sensitive sectors. In particular, this has been the case of the agricultural and textile sectors, where the Chilean counterpart has demanded the safeguards. For both sectors there are rules that the countries need to follow before a measure is applied ${ }^{13}$ and there are limits on the type of measures that can be applied. Normally, only tariffs are

\footnotetext{
${ }^{11}$ After the two-year period, a countervailing or anti-dumping duty can be requested for a product subject to safeguard measures, although to do so the requirements established by the law must be fulfilled.

12 In bilateral trade negotiations there is tension about safeguard disciplines. On the one hand, there is interest in supporting a sector that could be affected by the opening. On the other, there is also interest in defending the exporters who will be affected by the adoption of safeguard measures. The possibility to have the instrument and the compensation clause provide the construction of a politically acceptable balance.

${ }^{13}$ In some agreements, there are agricultural safeguards that are automatically applied. For specific products, this is the case of the Chile-United States free trade agreement.
} 
applied and they have to be the lowest between the level applied when the liberalization program started, and the tariff in force when the safeguard is adopted. Besides, compensation equivalent to the trade affected by the safeguard must be offered.

Finally, the terms and conditions to exempt one of the parties from the application of WTO safeguard measures has been considered. This has the effect of decreasing the effectiveness of the measure, as it generates incentives to divert trade towards the partner that is not affected by a measure. At the same time, it benefits exporters who are exempted from the measures

Therefore, in the safeguards regime applied by Chile, measures have a rather limited impact, due to both the general regime and the provisions negotiated in bilateral treaties. Its goal is to provide temporary relief as it is difficult to think that in a period of two years an industry can make an important economic adjustment. On the other hand, the legislation gives a strong signal to industries that suffer more permanent structural problems, in the sense that they will not be able to resort to this type of relief to promote an adjustment. Chile's legislation offers more adequate alternatives such as direct support to displaced workers. In the long-run, this could derive in political problems.. 
Table 5: Global Safeguards and Bilateral Agreements

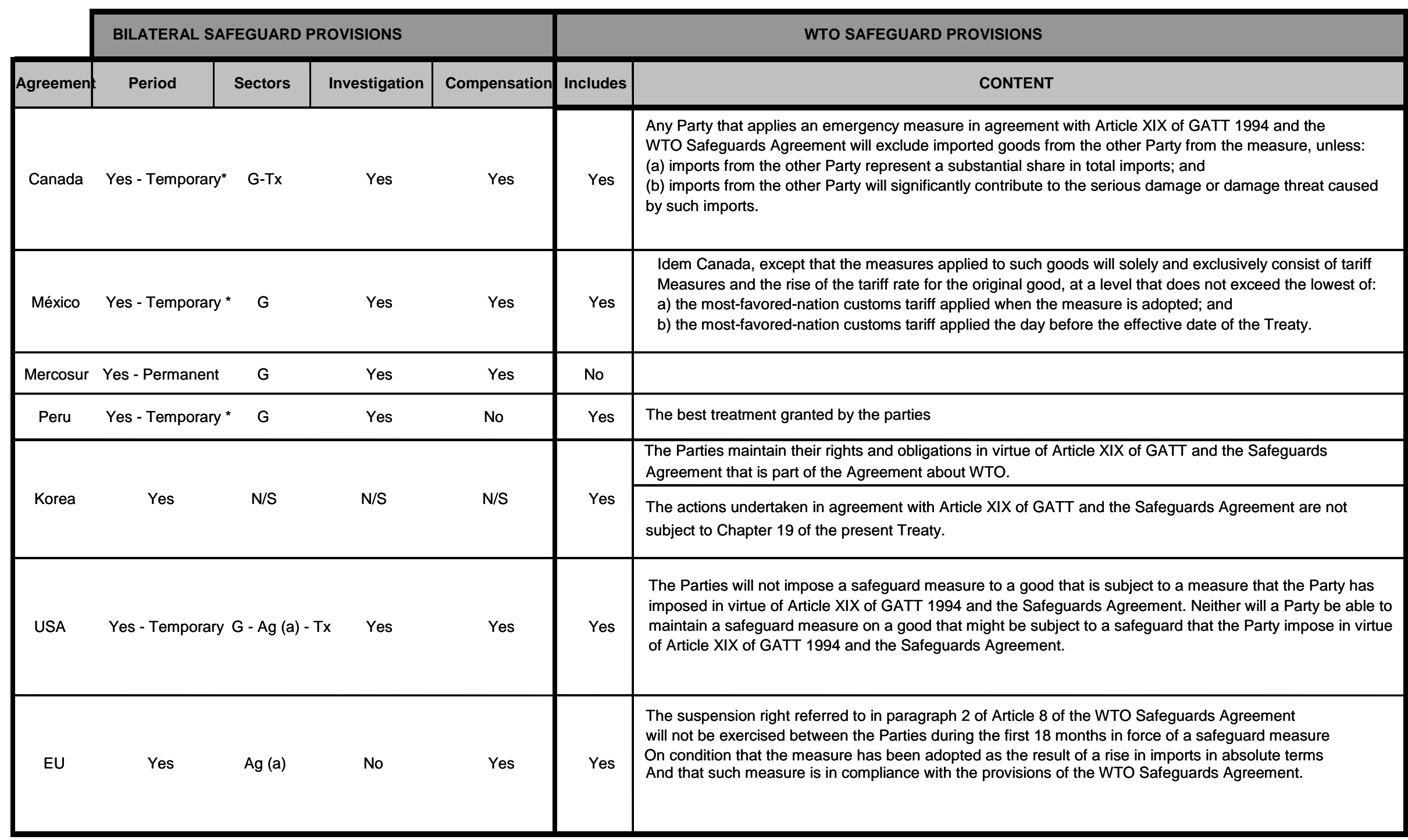

Source : DIRECON, Ministry of Foreign Affairs, www.direcon.cl.

Yes: It means that the bilateral Treaty contemplates a bilateral safeguard and/or has provisions for the application of WTO safeguards, including individualized elements,

such as investigation requirements and compensation.

Bilateral safeguards can be G: General, they can be requested for any economic activity.

In the agreements signed by Chile, there are sector safeguards, normally for the agriculture and/or the textile and clothing sector. In some cases the former are automatic.

$\mathrm{N} / \mathrm{S}$ : not specified in the agreement

$\left.{ }^{*}\right)$ : At the end of the transition period, an emergency bilateral measure can be adopted to face cases of serious damage or damage threat to

a national industry. 
Table 6: Safeguard Investigations, 1999-2003.

\begin{tabular}{|c|c|c|c|c|c|c|c|}
\hline $\begin{array}{l}\text { D.O. } \\
\text { Initiation } \\
\text { Date }\end{array}$ & $\begin{array}{l}\text { Name of } \\
\text { Product }\end{array}$ & $\begin{array}{c}\text { Measure } \\
\text { level }\end{array}$ & $\begin{array}{l}\text { Country } \\
\text { of Origin }\end{array}$ & $\begin{array}{c}\text { D.O. } \\
\text { Definitive } \\
\text { Measure } \\
\text { Date }\end{array}$ & $\begin{array}{c}\text { Measure } \\
\text { Effective } \\
\text { Date }\end{array}$ & $\begin{array}{c}\text { Measure } \\
\text { Termination } \\
\text { Date }\end{array}$ & $\begin{array}{l}\text { Measure } \\
\text { Duration }\end{array}$ \\
\hline $\begin{array}{c}9-09-1999 \\
\left(^{*}\right)\end{array}$ & $\begin{array}{l}\text { Wheat, flour, } \\
\text { sugar and } \\
\text { vegetable oils }\end{array}$ & Variable & All & 22-01-00 & $22-01-00$ & $26-11-00$ & 10 months \\
\hline $09-02-00$ & $\begin{array}{l}\text { Synthetic fiber } \\
\text { socks }\end{array}$ & $13 \%$ & All & 08-11-00 & $08-11-00$ & 27-04-01 & 4 months \\
\hline $04-11-00$ & $\begin{array}{l}\text { Wheat, flour, } \\
\text { sugar and } \\
\text { vegetable oils } \\
(* *)\end{array}$ & Variable & All & $25-11-00$ & $25-11-00$ & 27-11-01 & 12 months \\
\hline $21-06-00$ & $\begin{array}{l}\text { Powdered and } \\
\text { liquid UHT milk }\end{array}$ & $12 \%$ & All & 10-01-01 & $10-01-01$ & $13-07-01$ & 6 months \\
\hline $19-04-01$ & $\begin{array}{l}\text { Synthetic fiber } \\
\text { socks (***) }\end{array}$ & $6 \%$ & 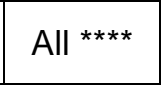 & 30-04-01 & $30-04-01$ & $31-10-01$ & 6 months \\
\hline $05-04-02$ & $\begin{array}{l}\text { Steel products: } \\
\text { hot-rolled steel } \\
\text { and wire rod rolls } \\
\text { and sheets }\end{array}$ & $10 \%$ & All **** & $16-07-02$ & $16-07-02$ & $16-07-03$ & 12 months \\
\hline 08-06-02 & $\begin{array}{l}\text { The remaining } \\
\text { fructose and } \\
\text { fructose syrups, } \\
\text { with a fructose } \\
\text { content over the } \\
\text { dry product } \\
\text { higher than } 50 \% \\
\text { in weight }\end{array}$ & $14 \%$ & 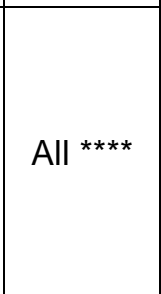 & 19-11-02 & 19-11-02 & $14-02-03$ & 3 months \\
\hline
\end{tabular}

$\left.{ }^{*}\right)$ As from this investigation they correspond to safeguard measures.

${ }^{* *}$ S Safeguard extension dated 22/01/00. For wheat and wheat flour, the measure was terminated by DH 244 exempted D.O. 27/07/01 and for vegetable oils, by DH 559 exempted, D.O. 20/11/01

$\left.{ }^{(\star \star *}\right)$ Safeguard extension dated 08/11/00

$\left.{ }^{\star \star \star \star \star}\right)$ Except imports from Canada, Mexico and Peru

Source: Central Bank of Chile, www.cndp.cl

In the 1999 - 2002 period, seven safeguard measures were adopted (Table 6). The traditional agricultural sector was the main user of the measures, which have been successfully questioned by Argentina and other trading partners in the context of the WTO. These questions led to the creation of an Expert Group to analyze the safeguard measures that Chile applied to wheat imports in the light of the provisions of the WTO Agreement ${ }^{14}$.

\footnotetext{
${ }^{14}$ The Expert Group analyzed two different matters: the price bands system that is applied to wheat, wheat flour and vegetable oil imports, and the safeguard measures that benefited these products. SEE WT/DS207/R, CHILE-PRICE BAND SYSTEM AND SAFEGUARD MEASURES APPLIED TO CERTAIN AGRICULTURAL, WTO.
} 
In this case, the Expert Group ruled against Chile, as it considered that it acted in a way that was incompatible with its obligations: i) by not providing the relevant Minutes of the sessions held by the Distortions Commission in an adequate means so that they could be considered a "published" report; ii) because the Distortions Commission failed to prove the existence of an unexpected development of circumstances, and because the report did not include grounded findings and conclusions in this respect; iii) because the Distortions Commission failed to prove the similarity or direct competition of products manufactured by the domestic industry and therefore, it did not identify the domestic industry; iv) because contrary to the WTO rules, the Distortions Commission did not prove the increase in imports of products subject to safeguard measures; v) because the Distortions Commission did not prove the existence of a threat of serious injury; vi) because the Distortions Commission failed to prove a causal relation; and vii) because the Distortions Commission did not make sure that the measures were limited to the measure that was necessary to prevent or repair the damage and facilitate the readjustment. Summing-up, the safeguard measures were not based on the requirements of Article XIX of GATT 1994 and the WTO Safeguards Agreement.

This shows that even when safeguard measures are applied in a more restrictive way than contemplated by the WTO Agreement, this is not a guarantee that the requirements of the Agreement are fulfilled. It is not enough to maintain a restricted safeguards regime to ensure adequate use of measures.

Another interesting case refers to the investigation of safeguards for steel imports. These safeguards were requested in the context of the safeguard measures adopted by the United States, and the adoption or threat of adoption of similar measures by the international community. Although measures were exclusively adopted for 3 types of specific products, included in 5 tariff items, the application made by the Chilean industry, requesting measures for 17 product categories classified in 21 items, was rejected. In this case, the opposition of steel product consumers was a determining to moderate the pressure for measures in favor of the industry as it showed the negative impact that they would have on the exports of manufactured products and consequently, on labor. 


\section{Review of the Chilean System}

The context in which the Commission was created in 1981 and the type of measures adopted by this entity support the idea that the objective of the Commission was to alleviate the political pressures generated by the difficult economic situation rather than to correct problems originated by the "price distortions of goods." In the second half of the 1980's, the Commission supported the liberalization process that started in 1985.

During the decade of the 1990's and until the present day, this philosophy has been maintained. The legislation has undergone modifications to adjust the instruments used to support the economic opening and international commitments. However, the use of these instruments has developed to target alleged distortions.

The law has maintained the criterion that measures should be effective for only one year and that their renewal entails a de novo investigation procedure, which implies an important cost for the applicant. That is also a signal, since the protection offered by this legislation is considered to be and is essentially temporary, and exceptional treatments are limited in time and in the type of instruments.

From the point of view of the operation of the Commission, the entry into effect of the WTO meant having to follow its procedures in accordance with the requirements of the anti-dumping agreement, and once safeguard legislation was adopted, the corresponding WTO agreement. An improvement on the procedures applied by the Commission to perform its duties is observed since its establishment till now. Its analytical methodology has been enhanced to fulfill the requirements of WTO agreements, including hearing and transparency procedures. Additionally, being subject to the review requirements of WTO Committees, the periodic notifications contemplated by the agreements, and the reviews of the Trade Policy Review Mechanism (TPRM) are also aspects that demand maintaining a discipline of the actions of the Commission and its decisions.

Since formal safeguard legislation was passed, the measures adopted have been subject of consultations and even of a panel held by the affected members of the WTO. This represents an important disciplinary element for the Commission, which is reviewing its procedures in order to improve them. The Commission has recently adopted measures to increase transparency and access to information. However, it has not been possible to prove the practical scope of these modifications, as there have been no new investigations. 
Chilean legislation is quite conservative, especially if compared with international practice. However, its application has not been free of criticism, and it is necessary to seek mechanisms that combine limitations set forth in the law and self-imposed limitations, that can change under pressure.

Some sectors consider that the performance of the Commission is not timely, as they would like the government to take a more decisive initiative to protect the industry without having to incur the costs of submitting applications. Additionally, these sectors consider that the procedures of the Commission are very slow, and that it reacts late, when the damage is already done. This criticism has sometimes been taken up by political sectors linked to the agricultural and textile sectors, which have lobbied for a more active performance of the Commission in favor of the sectors affected by "unfair competition."

On the other hand, both private sector representatives and academic economists consider that the safeguards and unfair competition systems are mechanisms that favor protectionist sectors which, sheltered by these situations, seek to elude the demands generated by the economic liberalization.

Although protectionist interests can capture these mechanisms -as is the case of many international legislations - that wish to avoid external competition, the Chilean experience shows that under certain circumstances, these mechanisms have supported the liberalization process. The crisis that took place at the beginning of the 1980's put the existing model in serious difficulty, so a more pragmatic approach was followed to conduct trade policy (Meller,1996). In this context, the creation of a mechanism to temporarily alleviate the strong demands for protection was a necessary step in order to continue pursuing the strategic goal of economic liberalization. In fact, as of 1985 an economic team orientated toward liberalization resumed the tariff reduction process. In March 1985, tariffs were uniformly reduced to $30 \%$ and later, in June of the same year, only three months later, they were again reduced to $20 \%$. Finally, in January 1988, tariffs were reduced to $15 \%$. However, even though the tariff reduction affected all sectors equally, a selective and temporary protection was established for politically "sensitive" sectors, especially for some agricultural products, textiles and shoes, through the Subsidies and Distortions Commissions, and probably through other less known means. Thus, this mechanism had a supporting role for the second liberalization process, which started in $1985^{15}$. This situation coincides with the arguments of Fischer and Prusa (1999), and Fischer and Osorio (2004), in the sense that in the context of negotiations between two or more countries, safeguard

\footnotetext{
${ }^{15}$ The first opening process started in 1973.
} 
and/or unfair competition clauses contribute to a more profound opening than the one that would be achieved without these mechanisms, and can even increase social welfare under certain conditions. In the context of a unilateral opening process as the one which prevailed in Chile, the possibility to selectively resort to a temporary protection had the same role.

In the decade of the 1990's, in the context of a democratic regime subject to periodic elections and the usual pressures of the system, maintaining an open economy rendered it more necessary to have a mechanism of this nature, which could grant some limited flexibility to conduct economic policy - more so when the system is subject to national and international rules that allow the authority to base its decisions on them.

What explains that Chile had been able to maintain this policy approach under a democratic regime, in spite of having undergone a strong economic deceleration process since 1998? The Chilean system for safeguards and unfair competition is part of a more general economic system. In fact, as Bauer (1998) points out, the Constitution of 1980 contains a set of economic principles. An important example is that in terms of taxes, the legal initiative to establish or modify any tax belongs to the Executive Power. Consequently, Congress members cannot take action in this area out of their own initiative. This provision does not prevent the Legislative Power from influencing, or seeking to influence tax or tariff matters, since as we have seen, safeguards legislation arises from a negotiation between both powers. But it implies that the leadership that the economic authority has in customs tariffs matters, supported by Constitutional provisions, is key to maintain the orientation of trade policy.

A second element that has contributed, is the existence of a relatively strong consensus on the global benefits of the economic reforms adopted since 1973. This means that there is, both in the business and political sectors, a favorable environment for economic policies that promote liberalization, although there are specific initiatives against it. This has not prevented certain sectors - such as the traditional agriculture sector and to a lesser degree the textile and steel industries - from receiving support for their demands for more protection from certain political sectors, although so far these demands have been limited.

However, there is scope to improve the Chilean system and grant it a higher level of autonomy and transparency. For example, at present the Commission is constituted by a majority of governmental representatives or members appointed by political authorities. Although in practice this does not mean that the Commission will adopt an active 
protectionist approach, there is no guarantee that it will not do so in the future or that it will be immune to pressure from interest groups. In fact, there are diverse mechanisms through which interested parties seek to exert pressure to influence decisions, such as organized demonstrations and even lobby activities.

Therefore, it is possible to consider modifying the composition of the Commission to include representatives appointed by a mechanism that will ensure a higher level of autonomy. This is something that occurs in few international experiences and therefore, it is relevant to analyze why this mechanism is normally under government control. This proposal poses the problem of securing a form of financing so that the Commission can have autonomy not only in terms of the appointment of its members but also, to operate. An aspect that must be assessed when considering a higher level of independence is the impact that this type of measure can have on international relations. As it was explained, when the Distortions Commission started operating, Chile suffered threats of trade retaliation if it adopted measures. Therefore, it is also necessary to assess how to adequately manage the international dimension of the possibility of greater autonomy for the institutionality, especially regarding safeguard mechanisms.

An additional aspect refers to the requirement that administrative measures linked to definitive determinations are to undergo reviews by courts or arbitration, judiciary or administrative procedures, as well as the review of determinations contemplated by the WTO Anti-dumping Agreement. In this respect, at present there are several mechanisms in Chile by means of which the decisions of the Commission can be reviewed. In the first place, one of the roles of the Contraloria General de la República is to control the administrative acts of the Executive Power. A second option is to have recourse to the "recurso de protección," which is widely used to protect the "economic public order" established by the Constitution with respect to private economic rights. This mechanism allows the request of an immediate judiciary review on the part of any person who feels that her/his economic rights are not respected by the state or by other private agents. The submission of this recourse must be immediately reviewed by the corresponding Appellate Court and is used to prevent or correct economic damage (see Bauer,1998).

However, this review mechanism could be improved by means of a specialized instance such as the recently created Competition Court. This is an option that could be considered as it would give more support to the decisions adopted by the President with respect to the recommendations of the Commission. Besides, it would be a protection against lobby actions or other forms of pressure that could be used and that are aimed at 
influencing the decisions of the Executive Power. Furthermore, the actual composition of the Commission could remained unaltered, as it would not be necessary to grant it the higher levels of independence proposed before.

Additionally, the Commission could improve even more in terms of transparency. As from the conclusions of the WTO panel, the Commission has worked to correct the its procedures, improving the information on the findings and the grounds for its conclusions that is available to the public. Access to information has also improved. However, we believe that there is more scope for change. For example, the Report of the Technical Secretariat could be made public by removing from it those sections that are considered confidential by the interested parties. Together with the Minutes of the Commission, where the findings and the grounds for decisions are recorded, it could be used to support its functioning more effectively and to understand better how it ponders the different evidence.

Finally, the Commission could have a wider approach to review applications. At present, a mandatory review of the impact of measures on domestic market competition and on consumers or users of the product that is subject to a measure is not incorporated in the respective WTO agreements, or in Chilean legislation. Although this can be considered, at present there is no obligation to do so and therefore, it is again subject to the criterion of the Commission. If we take into account that in many cases where measures have been requested the applicant has important market power (for example, the sugar, steel and matches sectors), these considerations are particularly relevant.

The improvements proposed are always limited by the political context of democratic regimes, and when we want to improve an instrument of this nature, efforts often result in a worse situation. Once more, the leadership role played by economic authorities is key to assess the need and opportunity to introduce these improvements. 


\section{REFERENCE}

Bauer, C.J. (1998): “Derecho y economía en la Constitución de 1980", Perspectivas Journal, Volume \# 2, Issue 1, November, Santiago de Chile.

Finger, J.M. (1987): "Antidumping and antisubsidy measures", in J.M. Finger and A. Olechowski (1987).

Finger, J.M. \& A. Olechowski (Eds) (1987): The Uruguay Round: A handbook for the Multilateral Trade Negotiations, World Bank.

Finger, J.M. Ed. (1993): Antidumping: How it works and who gets hurt, The University of Michigan Press.

Fischer, R \& T.J. Prusa (1999): "Contingent Protection as Better Insurance", www.dii.uchile.cl/ cea/pags/publicaciones/index.html

Fischer, R. \& M. Osorio (2004): "Why do we need Antidumping Rules?" www.dii.uchile.cl/ cea/pags/publicaciones/index.html

French-Davis, R. (1980): "Liberalización de importaciones: la experiencia chilena", in Colección Estudios de Cieplan $N^{\circ} 4$, November.

French-Davis, R. (2003): Entre el neoliberalismo y el crecimiento con equidad: tres décadas de política económica en Chile, 3rd edition, J.C. Sáez Editor, Santiago de Chile.

López-Ayllón, S. and G. Vega Cánovas, Editors (2001): Las prácticas desleales de comercio en el proceso de integración comercial en el continente americano: la experiencia de América del Norte y Chile, Biblioteca Jurídica Virtual, México.

Meller, P. (1996): Un siglo de economía política chilena (1890-1990), Editorial Andrés Bello, Santiago de Chile.

Peña, G. (2001): "Las prácticas desleales en los procesos de integración del continente americano: la experiencia chilena", in Las prácticas desleales de comercio en el proceso de integración comercial en el continente americano: la experiencia de América del Norte y Chile, Sergio López-Ayllón and Gustavo Vega Cánovas, Editors. 